\title{
Factors affecting the reputation of administrative furniture
}

\section{Majid Azizi}

College of Agriculture and Natural Resources, University of Tehran, Faculty of Natural Resources, Wood and Paper Sciences and Technology Department 16th Azar St., Enghelab Sq., Tehran, Iran

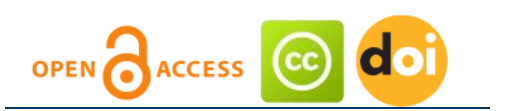

Article history:

Received: June 8, 2019

1st Revision: July 15, 2019

Accepted: September 12, 2019

\section{JEL classification: \\ D4 \\ L11 \\ Q13}

\section{DOI:}

10.14254/jems.2019.4-2.1

\begin{abstract}
The present paper aims at assessment and prioritizing of reputation factors affecting the administrative furniture. To this end, after basic studies and review of other researches, 45 sub-criteria under 6 basic criteria of management, customer, services, social-cultural, technical and marketingeconomic were recognized, and prioritized through analytical hierarchy process (AHP). To select the best criteria and sub criteria a questionnaire was designed and administered among 16 experts of furniture industry, and then evaluated considering the sub criteria. The results of synthesizing by AHP and Expert Choice software indicated that the main criteria of marketing -economic, customer, management and technical have respectively the highest scores, and also sub criteria of quality of product, customer loyalty, product price and the value of corporate brand have respectively been the most appropriate factors.
\end{abstract}

Keywords: administrative furniture, reputation, criteria, Analytical Hierarchy Process.

\section{Introduction}

The reputation of a company has attracted a lot of attention among marketing researchers (Walsh et al., 2006). Now, companies regardless of their location, have recognized the role and importance of organizational reputation. Organizational reputation from the viewpoint of many commentators can be considered as a source of strategic value. Organizational reputation is the result of customers' perceptions of direct and indirect experiences and information, and is shaped by previous activities of the company (Caruana \& Ewing, 2010). The benefits of having a good reputation include reducing operating costs, high rates of returning customers, and consequently increasing sales and the possibility of rising product prices (Inglis et al., 2006). The organization communicates with its customers through communication messages, advertising, public relations, websites, brands, logos and other tools. Organizational communication is shaped by the magnitude of the shareholder experience-responses and inferences, and fame (Bunting \& Lipski, 2000).

Corresponding author: Majid Azizi

E-mail: mazizi@ut.ac.ir

This open access article is distributed under a Creative Commons Attribution (CC-BY) 4.0 license. 
Branding is the creation of appropriate competition between manufacturers and exporters so as to increase real competitive ability among them. The establishment of brands in the furniture industry not only helps the Iranian consumers choose the best domestic products, but it also paves the way for expansion into other countries and helps develop export. Ghazanfari (2008) stated that from the point of view of export, which is $50 \%$ of commerce, most challenges faced by exports arise from the non-existence of brands. Chinguwa et al. (2013) stressed that furniture manufacturers should gather information from the furniture market in order to be aware of the market situation, and also to be able to optimize their products according to the needs of the customers. Factors affecting competitiveness in furniture industry concentrates on the upstream section of the value chain and examines the role of raw materials and components, labor costs and the availability of skilled labor, of investment in technology, R\&D, innovation and design (Renda et al., 2014).

In his thesis titled "Comparison of chain store customers' loyalty", Karimi (2011) employed AHP, whereby he found that customers' trust, satisfaction and loyalty do not have a meaningful differences and that the factor that determines the supremacy of a store is quality. Khorshidi and Kardgar (2009) explained and ranked factors that contribute most to customers' loyalty, using multi-criterion decision-making methods. The present research aim to assess and prioritize reputation factors affecting administrative furniture industry. In this respect, it could be supposed that customer's loyalty and quality are among the most important factors affecting reputation in administrative furniture industry.

\section{AHP for determination of priority rate (weighing value) of each criterion}

AHP is a method for decision-making by which we can make some decisions depending on several criteria or multi-criteria decisions. By AHP method, first, the given structure and then the criteria relevant to decision making are compared to each other, and then the priority rate of each one is determined. Numbers which are used in two-by-two comparisons are from $1 / 9$ to 9 which is in the form of a standard scale (Saaty, 2000). Application of AHP is based on the following three principles (Asgharpour, 1999): A. Establishment of a structure and a rank-based from for the problem, B. Establishment of preferences by two-by-two comparison, C. Establishment of logical consistency from measurement. The mechanism to apply this method is such that after the hierarchy is drawn up for six criteria and forty five sub-criteria influencing the reputation of administrative furniture industry and after the questionnaire is prepared as the two-by-two comparison of criteria and sub criteria, the opinions of 16 experts will be asked about the priority rate of these criteria and sub criteria against each other in the form of dual comparison matrices. Then, the priority rates of each one of the criteria and sub criteria are compared and first geometric mean is calculated for each one of the matrix cells using the following formula (Memariani \& Azar, 1995):

$$
\text { Group judgment } \mathrm{a}_{12}=\left(\mathrm{a}_{12} 1 * \mathrm{a}_{12} 2 * \ldots * \mathrm{a}_{12} \mathrm{~N}\right)^{1 / \mathrm{N}}
$$

After the geometric means of all matrix cells are calculated, the results are normalized, and the criterion and sub criterion weighing value are obtained through the integration of the weight of the low-level elements into the weight of the related up-level elements of the hierarchy. One point to be notified here is the inconsistency ratio of the matrices, which according to Saaty (2000), the inventor of AHP method, if the judgments are consistent, it is necessary that the inconsistency ratio of the matrices to be equal or less than 0.1 , therefore if in some matrices the comparison is greater than 0.1 it is necessary that the relevant expert repeat his judgment, so that the matrices are consistent, and then the geometric mean of the matrix cells of the comparison matrices are calculated. One can find some studies in which the AHP is applied for decision making. The background information on the studies shows that there are several researches where AHP has been applied. One example is making a decision regarding the establishment of commercial ties with China (Saaty \& Cho, 2001). They concluded Preferred Normal Trade Relations (PNTR) was the best choice. Azizi (2005) applied AHP to determine effective criteria for selecting the best choice of raw material procurement in paper making factories in Iran. The decision was made on the basis of benefits, costs, opportunities and risks. The results showed no harmful effect on the environment to have the highest priority in terms of benefits. Memariani et al. (1992) applied AHP method to determine the rate of priority of the effective criteria for selection of the best variety for wheat seed and reported that this method provided significant facilities for analysis of decision making issues and determination of effective criteria in decision making process. The AHP that is applied in general problem solving processes was adapted to the problem of selecting the location for furniture industry firms in Turkey (Burdurlu \& Ejder, 2003). 


\section{Identifying and structuring a hierarchy model for prioritization}

On the basis of some literature review a number of elements were chosen. In this research, the six main groups of reputation in administrative furniture were categorized as economic \& marketing approach, management's approach, customer's approach, service's approach, social and cultural approach and technical approach. Economic \& marketing approach included four types of sub criteria: quality, product price, brand and packing. Management's approach divided into two criteria in second level: organization and personnel. Organization included eight sub criteria: brand strategy, supervisory staff behavior, promise, culture in the organization, transparency of services, standards, customer relationship and compensation, also personnel divided into seven sub criteria: encourage and promote, deal with customer, recruitment of qualified staff, transfer of authority, attitude change, creativity and skills. Customer's approach subdivided into customer loyalty, satisfaction, expectation and values, identify needs and trust, company business, participation in decision making and continuous communication. Service approach included two criteria in second level: before sale services and after sale services. Before sale services divided in four sub criteria: design and layout before order, description of the methods, information and description of network develop. After sale services included two sub criteria in third level: delivery and attention to complains. Delivery divided in speed \& accuracy in providing and delivery on time. Social \& cultural approach subdivided into utilization of information technology, attractive advertising, surveys and feedback system, installation of store location and email marketing. Technical approach includes two sub criteria: use of modern machinery and knowledge. A tree-level hierarchy was structured to facilitate the prioritization process (Figure 1). The tree is segmented into three levels: the top level contains the reputation administrative furniture industry elements; the second level contains the six categories and, in the third level, there are 45 sub- criteria in total.

Figure 1: A hierarchy model of reputation effective criteria in administrative furniture industry

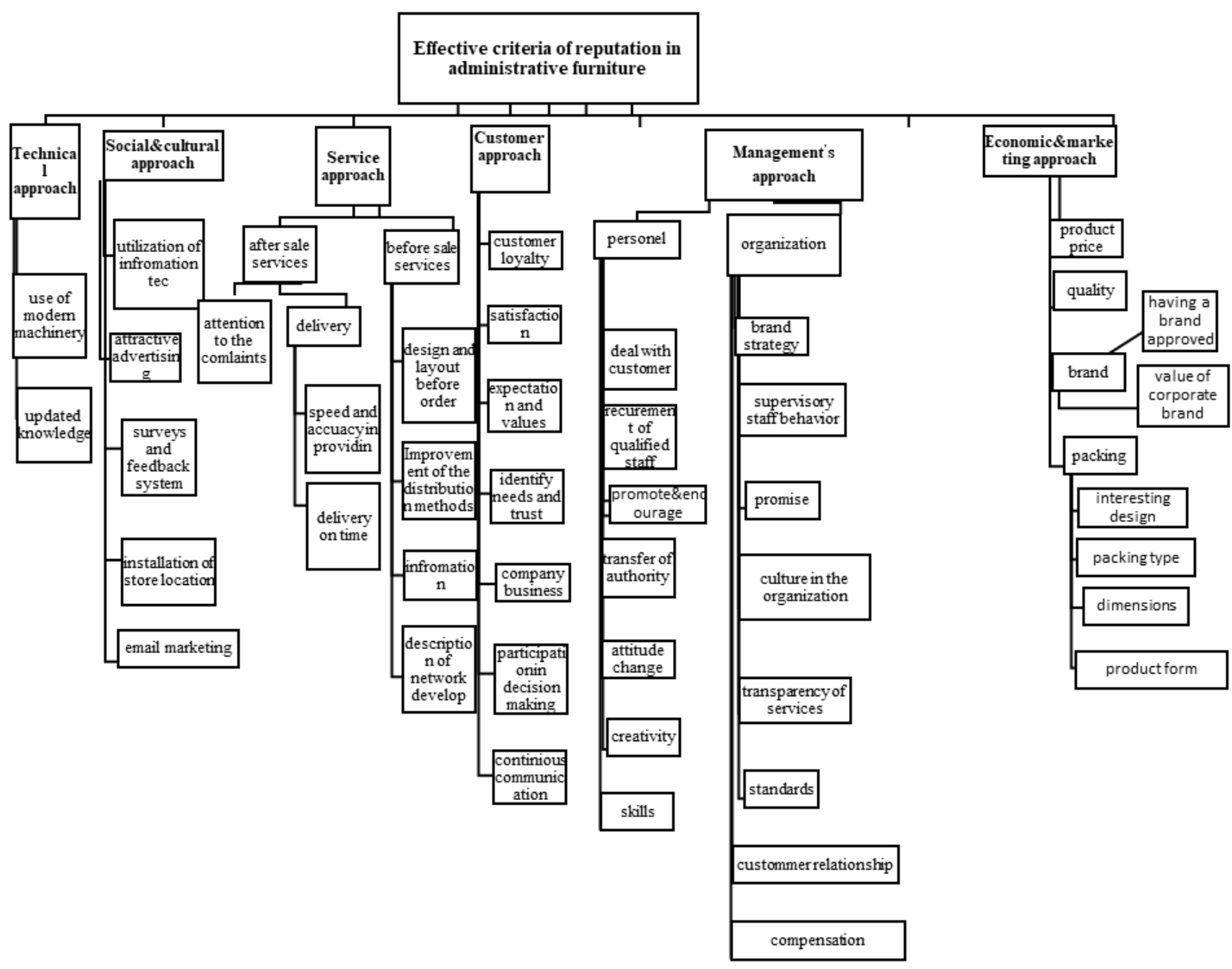


All of criteria and sub criteria described as the following:

1. Management approach: Management is to work through others to achieve the goals of the organization and employees (Haghighi et al., 1999).

1.1. Personnel: people employed in an organization or engaged in an organized undertaking.

1.1.1. Encourage and promote: Promote people's position, increase their salaries and pay attention to well-being and improve the quality of life of employees through education, participation in decision making, performance and job security.

1.1.2. Deal with customer: It means managing and controlling the ethics and behavior of employees in a healthy and beneficial deal with customers.

1.1.3. Recruitment of qualified staff: The purpose is to hire and train qualified and knowledgeable employees who have the necessary skills in establishing the right, logical and sustainable communication.

1.1.4. Transfer of authority: Transfer of authority is a key component of empowerment. This will enable employees to take care of the needs of the client and solve their problems in a timely manner.

1.1.5. Attitude change: Occasionally, employees create new attitudes in their business decisions in order to provide customer satisfaction, and initiatives are taken to resolve customer problems that are not foreseen in the framework of regulations.

1.1.6. Creativity: Creativity means directing staff toward creative activities. More creativity give rise to more empowerment.

1.1.7. Skill: In order to improve and strengthen the skills of employees in the workplace, it is necessary to provide guidance through empowerment through inclusive education.

1.2. Organization: An organization is an entity comprising multiple people, such as a furniture company, that has a particular purpose (Haghighi et al., 1999).

1.2.1. Brand strategy: By designating a strategy, firms establish a specific, or unwritten, identity. The establishment of such an identity and its development create a special value for the customers, whereby the firm is distinguished and will be safe among rivals. Brand strategy paves a specific way for the managers and leads and controls organizational branding plans, and consequently creates profit and productivity margin.

1.2.2. Supervisory staff behavior: Employee behavior is now incorporated into the organization's ethical charter and the rules of professional conduct of the core business within the organization. One of the most important factors affecting customer satisfaction is the monitoring and attention of the organization on customer behavior and attitudes.

1.2.3. Promise: a legally binding declaration that gives the person to whom it is made a right to expect or to claim the performance or forbearance of a specified act.

1.2.4. Culture in the organization: Values are the accepted beliefs of a group in carrying out activities aimed at generating or creating value added.

1.2.5. Transparency of services: Transparency means increasing the information and awareness of people about how and how to provide services and products to customers.

1.2.6. Standards: The standard is the first step in optimization. Standardization is more effective in some design areas that are less exposed to business pressures or lightweight variations.

1.2.7. Customer relationship: Public sector clients are looking for quick, accurate, and available information. Therefore, contacting the customer by post or sending a catalog, the introduction of products and services at the door and at the work place of the buyer is a good result.

1.2.8. Compensation: Compensation means that if the goods are damaged at any stage (transports, installed at home or at work), the company must pay damages. The firms are obliged to compensate.

2. Economic \& marketing approach: Economic developers must be adept at implementing marketing strategies to promote their communities and grow their local economies. Many economic development agencies are responding to these changes through the way they market their communities and provide their services (Mahdavinia, 2002).

2.1. Quality: a measure of excellence or a state of being free from defects, deficiencies and significant variations. It is brought about by strict and consistent commitment to certain standards that achieve uniformity of a product in order to satisfy specific customer or user requirements.

2.2. Price: A value that will purchase a finite quantity, weight, or other measure of a good or service. 
2.3. Brand: Unique design, sign, symbol, words, or a combination of these, employed in creating an image that identifies a product and differentiates it.

2.3.1. Value of corporate brand: The brand is the property of a company, which adds value to the final product. Firms gain credit through the brand. A set of assets and capabilities associated with the brand is the name and symbol of the company that adds value created by the product or service to the company or consumers of the companies.

2.3.2. Having a brand approved: A recognized brand is a combination of meaning and behavior, part of the consumer brand-members of the distribution channel and the source of participation, and allows the brand to gain more profit than it did when it was not branded.

2.4 Packing: Packaging is the container or package in which the product is marketed for sale, and then the requirement information is transmitted to the consumer.

2.4.1. Packing type: The appropriate packaging affects the morale of the consumer society. This package, through visual communication, transmits complete information about the product and the manufacturer to the addressee or the consumer.

2.4.2. Interesting design: After identifying the different dimensions of customer expectations and convert expectations into proper features in the design phase, turning to the production of goods or services is based on the design features.

2.4.3. Dimensions of the product: A product's physical dimension measures the tangible product itself and includes such things as length, weight, and moisture.

2.4.4. Product form: The shape of company's package can say a lot about company's product.

3. Customer's approach: A customer is an individual or business that purchases another company's goods or services. Most public-facing businesses compete with other companies to attract customers, either by aggressively advertising their products or by lowering prices, in an effort to expand their customer bases (Mahdavinia, 2002).

3.1. Customer loyalty: Customer loyalty is a measure of how likely company's customers are to do repeat business with the company. Different industries have various ways of measuring loyalty, but the most basic way is to look at the number of purchases over a customer's lifetime in company's database.

3.2. Satisfaction: It is a measure of how products and services supplied by a company meet or surpass customer expectation. Customer satisfaction is defined as "the number of customers, or percentage of total customers, whose reported experience with a firm, its products, or its services (ratings) exceeds specified satisfaction goals."

3.3. Expectation and values: Consumer expectations reflect both past and current product evaluation and user experiences. This information influences our expectations and gives us the ability to evaluate quality, value, and the ability of the product or service to meet our needs and expectations.

3.4. Identify needs and trust: To identify needs, the company must both listen and ask the right questions. After identifying needs, always check for additional or related needs. Use company's knowledge and experience to identify and present the right products, services, and solutions to meet customers' needs.

3.5. Company business: Company business is a company's plan for making a profit. It identifies the products or services the business will sell, the target market it has identified, and the expenses it anticipates.

3.6. Participation in decision making: Participation in the decision-making process gives each employee the opportunity to voice their opinions, and to share their knowledge with customers. While this improves the relationship between employee and customers, it also encourages a strong sense of teamwork among workers and customers.

3.7. Continuous communication: The key to maintaining continuous customers is to regularly communicate and identify the ways you can provide additional assistance year-round. Even if the company have just one single busy season, it can maintain contact with company's customers throughout the year through purposeful communication.

4. Service approach: Customer service is the process of ensuring customer satisfaction with a product or service. Often, customer service takes place while performing a transaction for the customer, such as making a sale or returning an item (Mahdavinia, 2002).

4.1. Before sale services: before sales service is what can ultimately lead to an after-sales service requirement as the sale would have been made. That's why a marketer must associate high priority to before sales service.

4.1.1. Design and layout before order: Draw, design and layout of the environment in software like AutoCAD and three D. Max, with the goal of understanding the best of the customer's product. 
4.1.2. Improvement of the distribution methods: Manufacturers lean more on channels of distribution to make their products available in today's broadening and maturing markets.

4.1.2. Information: Information that must be provided by the manufacturer to the customer to make the product better for the customer, such as price, quality, standard, functional characteristics, useful life, etc.

4.1.3. Description of network develop: A distribution network is the person or organization that helps to move a product or service from the manufacturer to the final consumer.

4.1.4. After sale services: After sales service refers to all the things a company does for the care and feeding of company valued customers after they buy the product.

4.1.5. Delivery: Delivery is the process of transporting goods from a source location to a predefined destination.

4.1.6. Speed \& accuracy in providing: Accelerate the work desired by the client and the correctness of the results of the work done and correct the mistakes of employees.

4.1.7. Delivery on time: Delivery without defects in the exhibition or door to the customer.

4.1.8. Attention to complains: To keep company's customers coming back, paying attention is a most valuable asset. Listen to your customers and hear what they are saying and feeling.

5. Social \& cultural approach: The socio-cultural approach is based on the idea that society and culture shape cognition. Social included customs, beliefs, values, and language (Mahdavinia, 2002).

5.1. Utilization of information technology: An organization can develop and becomes dynamic if information system exists. The impact of IT on increasing the quality, productivity, efficiency of products and services is economic growth with minimal environmental pollution and the least need for materials and energy.

5.2. Attractive advertising: Advertising is a means of communication with the users of a product or service. Advertisements are messages paid for by those who send them and are intended to inform or influence people who receive them.

5.3. Surveys and feedback system: A customer feedback system can provide real and tangible benefits to an organization that wants to get closer to its customers and staff. Using survey feedback system helps the company to focus on effective action plans.

5.4. Installation of store location: This method helps the company to create a list of mobile subscribers in each postal area and send the addresses of stores near their place of residence by SMS. Sending SMS to mobile can be beneficial if purchasers do not have access to the Internet at any given moment.

5.5. Email marketing: The process of creating and maintaining useful cross-relationships with customers through online activities to facilitate the exchange of ideas-goods and services that meet the goals of both parties.

6. Technical approach: This approach involving the sorts of machines, processes, and materials that are used (Mahdavinia, 2002).

6.1. Use of modern machinery: Modern machinery provides superior quality equipment, new and used, from leading industry manufacturers to help get company done.

6.2. Updated knowledge: The purpose is to have new or complete technical information or technical knowledge in response to customer questions and their needs today.

\section{Developing the questionnaire and collecting data}

The next step in AHP is data collection. This was done through a systematic series of pairwised comparisons among the specific criteria and sub-criteria. Pair-wised comparisons allow respondents to focus on only two criteria at a time, thereby, translating the complex, multi-criteria prioritizing problem into a series of pair-wised assessments. The pair-wised comparison matrices were completed with the aid of 16 experts from administrative furniture industry. The AHP then converts these comparisons to criteria weights using a matrix algebra-based algorithm while also checking for consistency in the results.

\section{Determining the normalized weights}

With the completion of the pair-wised comparisons, mathematical computations were conducted. The first step in the evaluation was to normalize each matrix by adding the values of each bxy. So, a matrix (B) can be normalized as follows: 


$$
\begin{aligned}
B & =\left(\begin{array}{cccc}
b_{11} & b_{12} & \cdots & b_{1 n} \\
b_{21} & b_{22} & \cdots & b_{2 n} \\
\vdots & \vdots & & \vdots \\
b_{n 1} & b_{n 2} & \cdots & b_{n n}
\end{array}\right) \\
& =\left(\begin{array}{cccc}
1 & b_{12} & \cdots & b_{1 n} \\
1 / b_{12} & 1 & \cdots & b_{2 n} \\
\vdots & \vdots & & \vdots \\
1 / b_{1 n} & 1 / b_{2 n} & \cdots & 1
\end{array}\right) .
\end{aligned}
$$

Then, the local weight $\mathrm{W}_{\mathrm{Bi}}$ was calculated according to the following formula:

$$
W_{B i}=\frac{\left[\prod_{j=1}^{n} b_{i j}\right]^{1 / n}}{\sum_{i=1}^{n}\left[\prod_{j=1}^{n} b_{i j}\right]^{1 / n}}
$$

After determining the local weights, the global weights of each criteria and sub-criteria were calculated. To avoid misdirection analysis, affected by interviewees' incompatible judgments, AHP establishes a consistency indicator as the standard judgment if the values are incompatible. The questionnaires involved in incompatible judgments were usually discussed with the respondents. Only the matrices that passed the consistency test were included in the final analysis.

\section{Results and discussion}

In order to determine reputation effective criteria and sub criteria of administrative furniture industry, 6 main criteria and 45 sub-criteria were evaluated (Figures 2). Among main criteria and sub-criteria 'economic \& marketing approach' and 'quality of product' reached the highest priorities, respectively (Figure 2-14). The results indicates two groups of criteria are more important in this research which are economic \& marketing and customer approaches.

Final prioritizing of effective reputation indicators identified in the furniture industry shows quality of the product, customer's loyalty, price of the product, value of corporate brand have the highest priority respectively (Figure 14). General inconsistency ratio of comparisons was 0.05 , indicating high stability and consistency of the results.

Figure 2: Result of main criteria priorities (Inconsistency ratio=0.07)

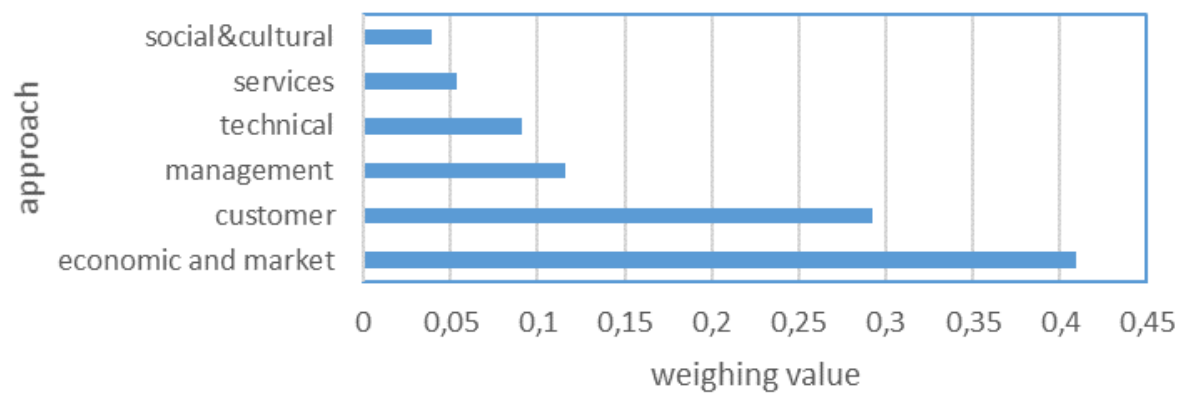


Figure 3: Result of management sub criteria weighing value (Inconsistency ratio=0.00)

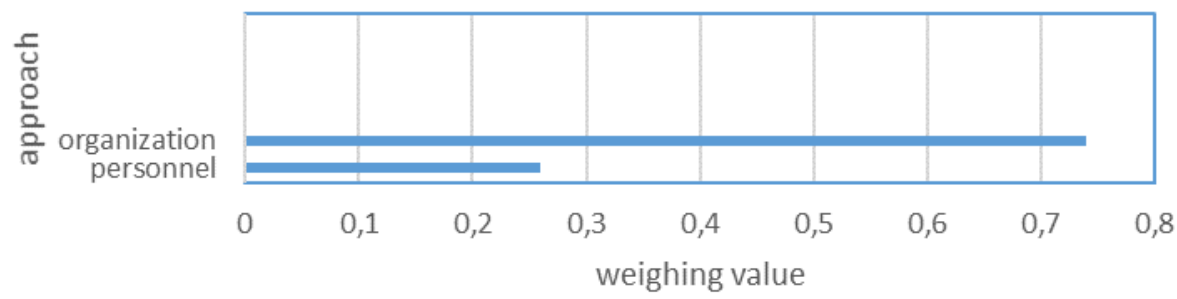

Figure 4: Result of personnel sub criteria weighing value (Inconsistency ratio=0.06)

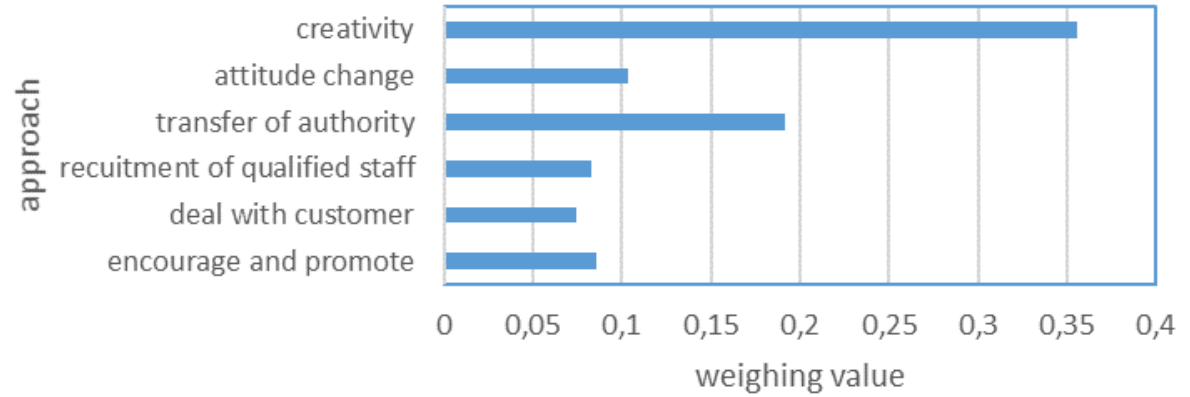

Figure 5: Result of organization sub criteria weighing value (Inconsistency ratio=0.00)

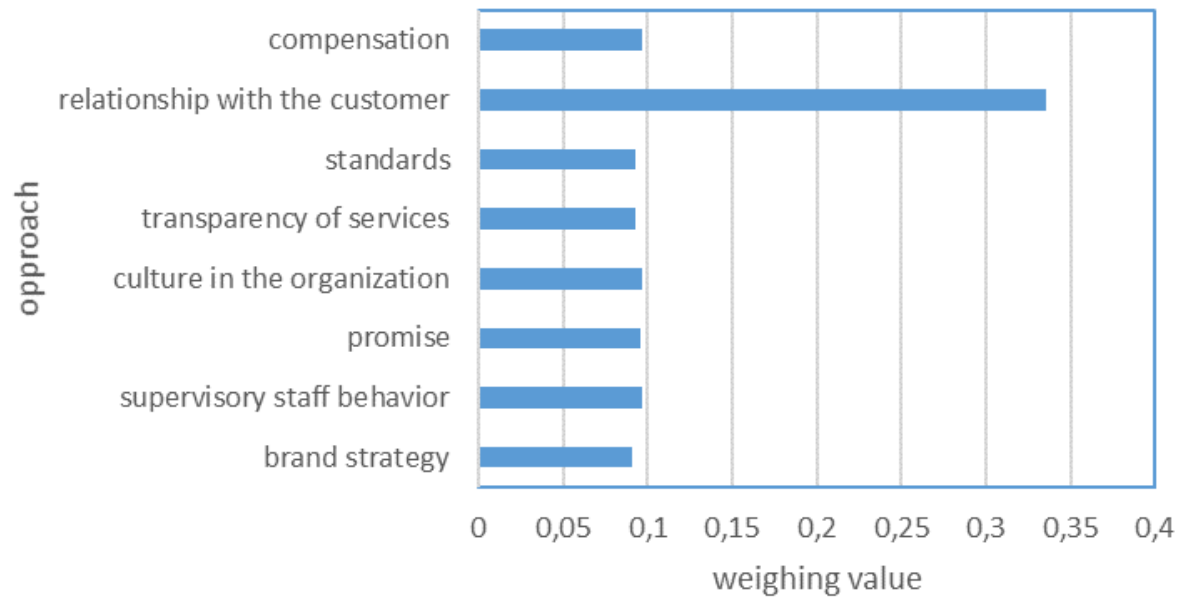

Figure 6: Result of customer's approach sub criteria weighing value (Inconsistency ratio $=0.05$ )

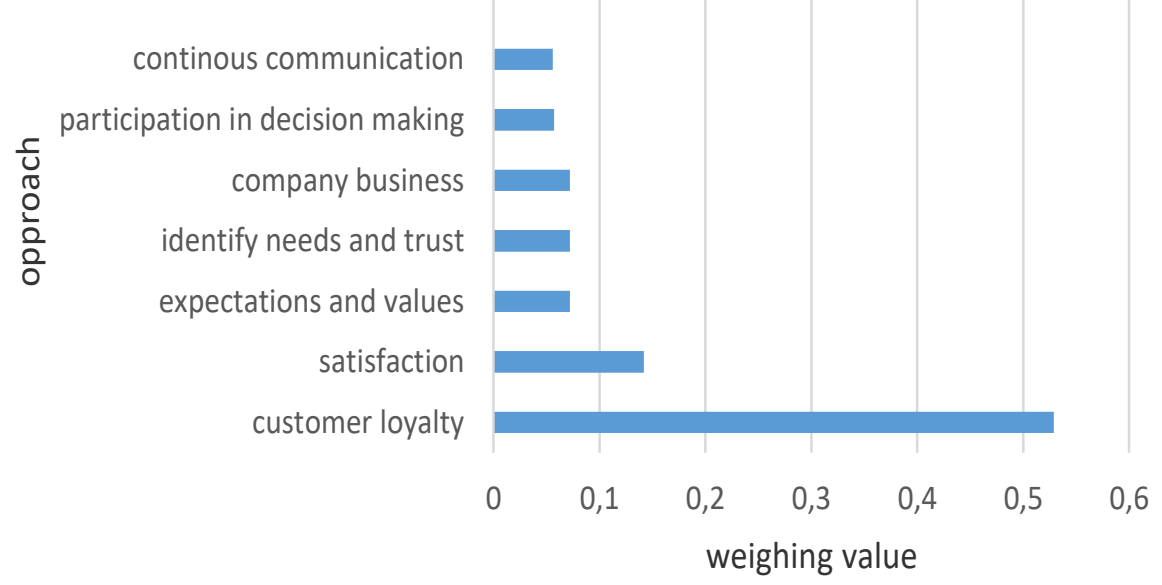


Figure 7: Result of services before sale sub criteria weighing value (Inconsistency ratio $\mathbf{0 . 0 0}$ )

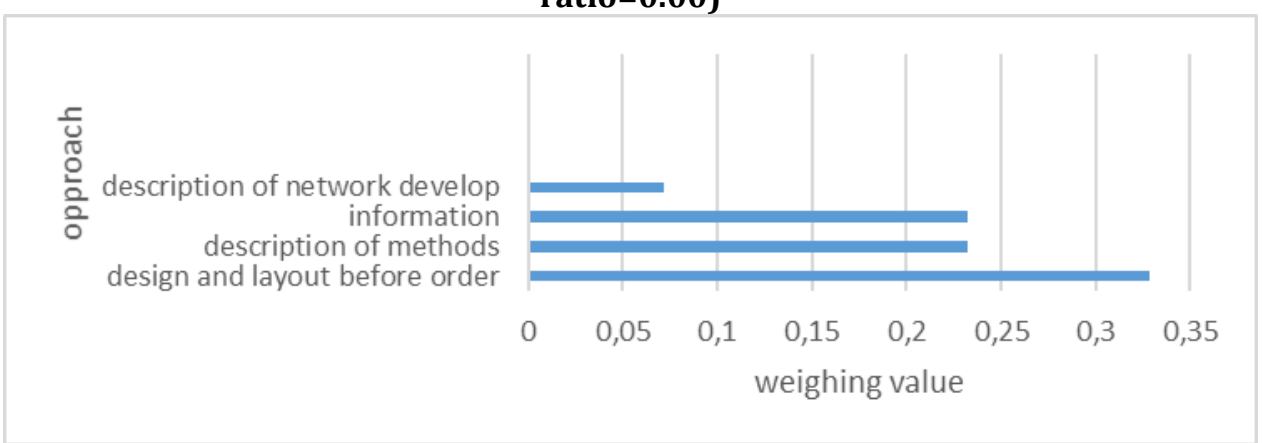

Figure 8: Result of services after sale criteria weighing value (Inconsistency ratio=0.00)

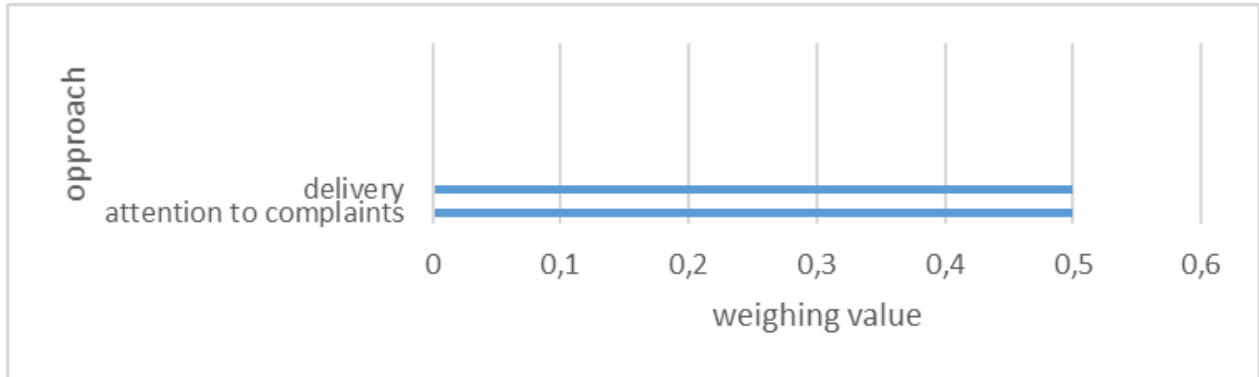

Figure 9: Result of delivery sub criteria weighing value (Inconsistency ratio=0.00)

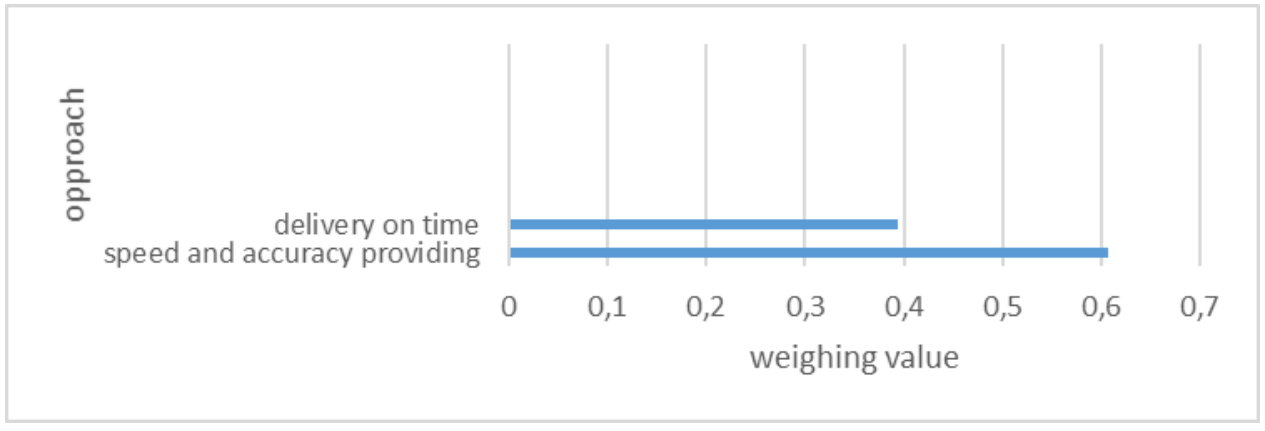

Figure 10: Result of social and cultural approach sub criteria weighing value (Inconsistency ratio $=0.01$ )

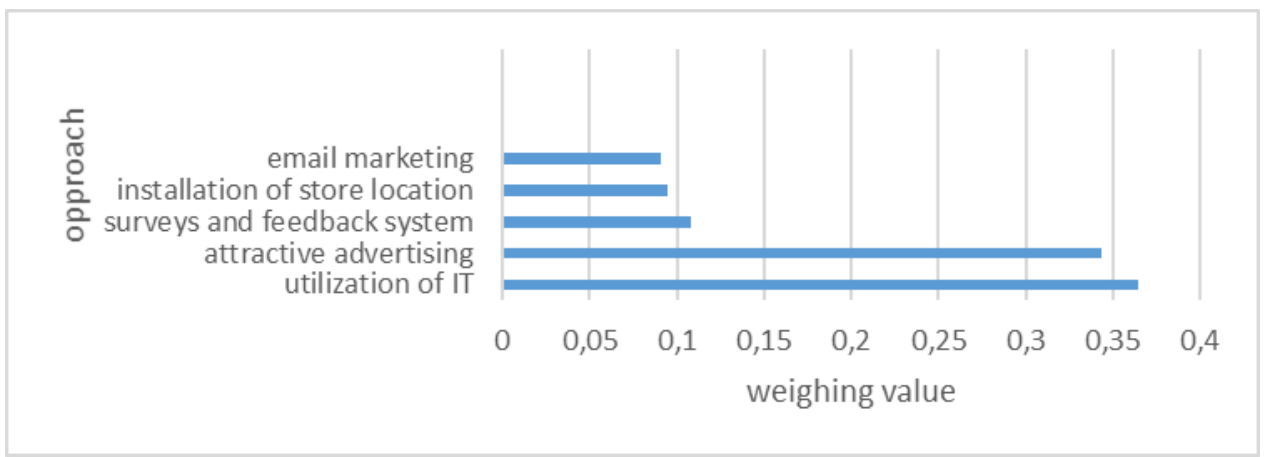


Figure 11: Result of technical approach criteria weighing value (Inconsistency ratio=0.01)

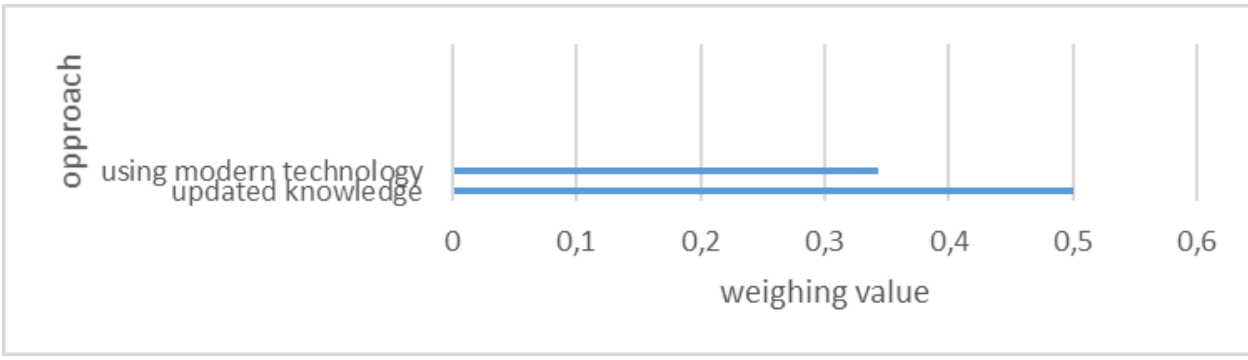

Figure 12: Result of economic and marketing sub criteria weighing value (Inconsistency ratio $=0.09$ )

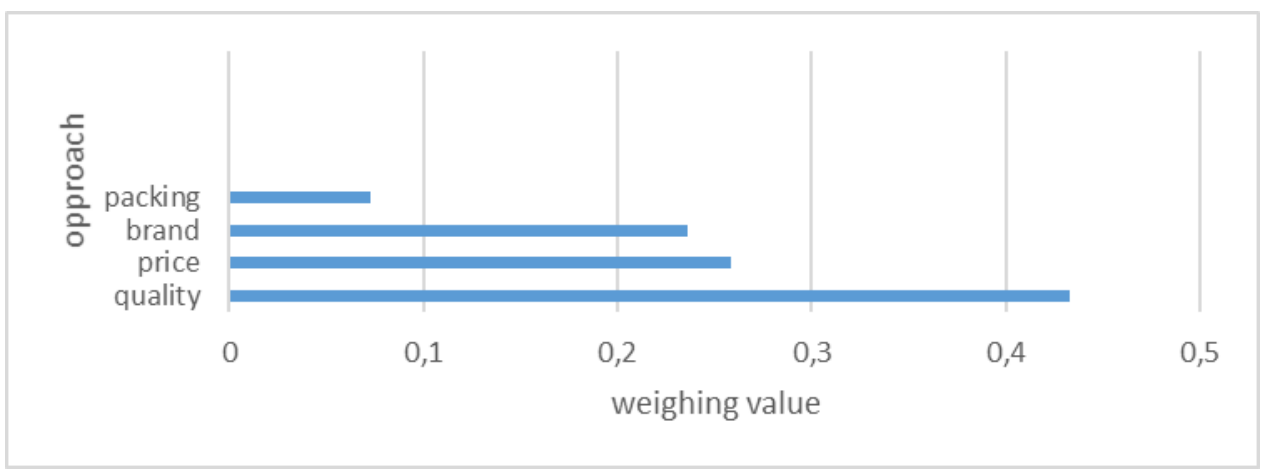

Figure 13: Result of packing sub criteria weighing value (Inconsistency ratio=0.02)

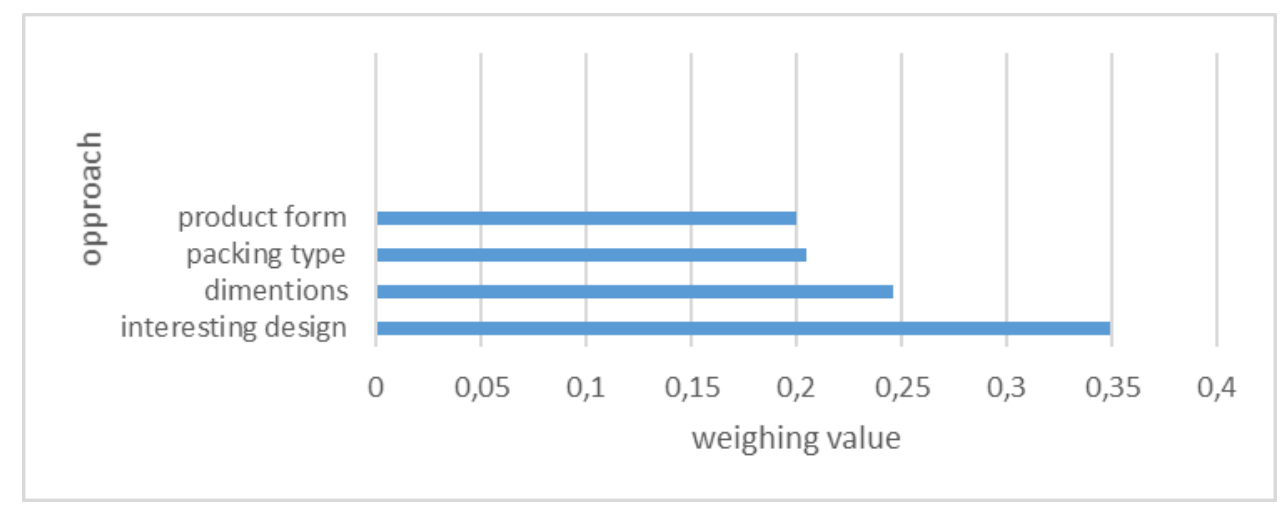

Figure 14: Result of brand sub criteria weighing value (Inconsistency ratio=0.00)

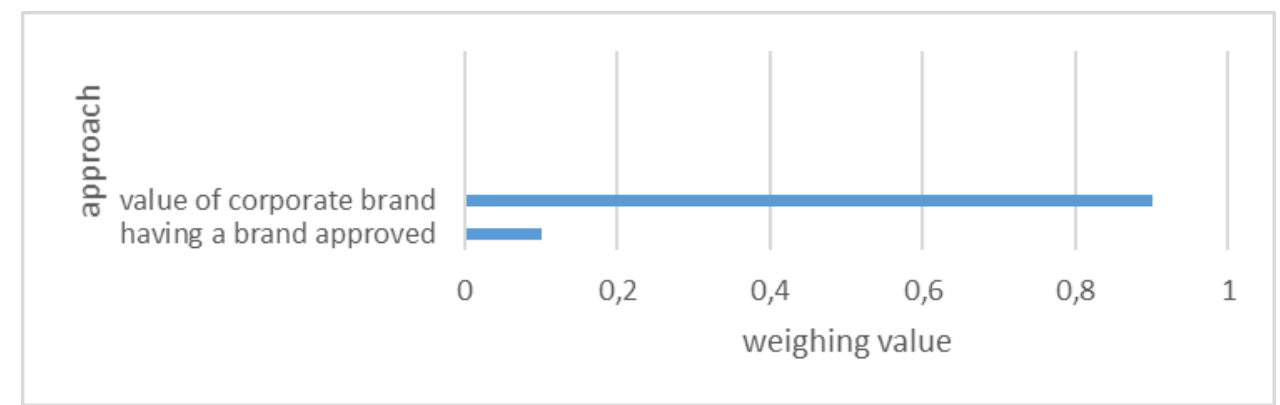


Figure 15: Overall synthesize of result of reputaion effective criteria in administrative furniture industry (Inconsistency ratio=0.05).

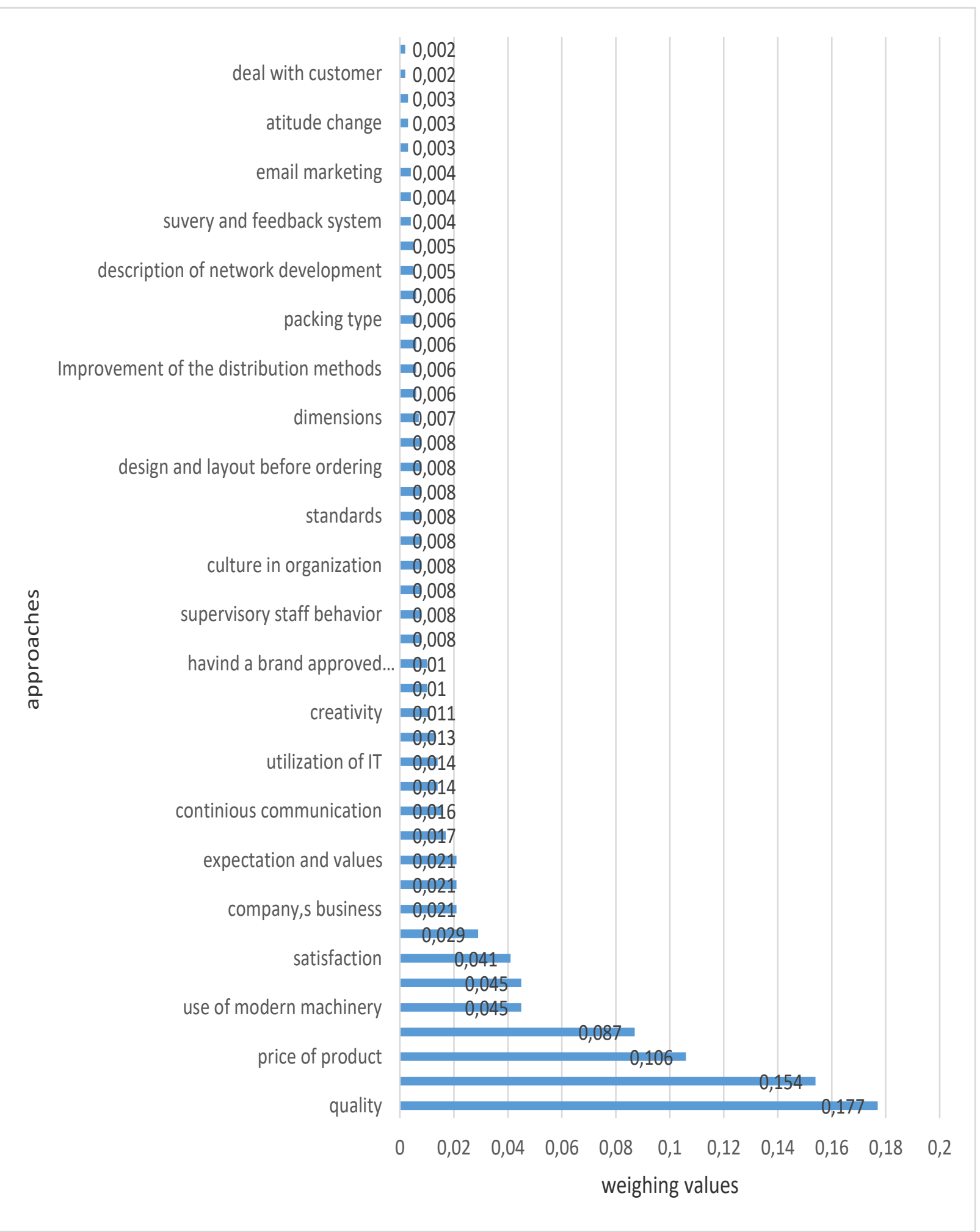

\section{Discussion}

In the analysis of the reasons for the heavy weighting and high importance of these indicators from the point of view of furniture industry experts and manufacturers, the following are some highlights: 


\section{Quality of the product $(0.177)$ :}

Quality is critical to satisfying company's customers and retaining their loyalty so they continue to buy from the company in the future. Quality products make an important contribution to long-term revenue and profitability. They also enable company to charge and maintain higher prices.

Quality is a complex and multifaceted concept. In its broadest sense, product quality is the ability of a product to meet or exceed customer's expectations (Waters, 2011).

Quality reflects on the company's reputation. A strong reputation for quality can be an important differentiator in markets that are very competitive. Poor quality or product failure that results in a product recall campaign can lead to negative publicity and damage your reputation. Quality is a key differentiator in a crowded market. Poor quality increases costs. If you do not have an effective quality-control system in place, you may incur the cost of analyzing nonconforming goods or services to determine the root causes and retesting products after reworking them.

In some cases, the company may have to scrap defective products and pay additional production costs to replace them. If defective products reach customers, company will have to pay for returns and replacements and, in serious cases, company could incur legal costs for failure to comply with customer or industry standards. Quality is a set of characteristics that result in the success of goods or services, in meeting the customers' needs and gaining control of the market. Making right decisions to increase quality is the only means of survival in domestic and foreign markets ((Tayyar, 2012).

\section{Customer's loyalty (0.154):}

Customer loyalty is a customer's willingness to buy from or work with a brand again and again, and it's the result of a positive customer experience, customer satisfaction, and the value of the products or services the customer gets from the transaction.

Customer loyalty helps business to improve brand image. As brand has already won trust of loyal customers, they are more likely to share positive experience than new customers. This eventually helps a brand to retain more customers and improve customer loyalty as well as brand loyalty.

Different industries have various ways of measuring loyalty, but the most basic way is to look at the number of purchases over a customer's lifetime in the company database. Repeat buyers are your most valuable customers. Customer loyalty is the result of consistently positive emotional experience, physical attribute-based satisfaction and perceived value of an experience, which includes the product or services. Retaining customers is less expensive than acquiring new ones, and customer experience management is the most cost-effective way to drive customer satisfaction, customer retention and customer loyalty. Not only do loyal customers ensure sales, but they are also more likely to purchase ancillary, high-margin supplemental products and services. Loyal customers reduce costs associated with consumer education and marketing especially when they become net promoters for the company. Loyal customers always purchase the goods or services again and again over time. On the basis of business type and sales cycle the suppliers may end up selling more to loyal customers in a year than to the first time customers. Customer's loyalty helps to make customers purchasing the goods and services again and again over time. It uplifts the positive way to run the business and increase the number of customers and sales too. The loyal customers always spend more money to buy the products that protect the business from the competitor and also reduce the risk of price sensitivity (Ranabhat, 2018). Loyal customers talk about goods with other people and it brings new customers. Today the new business spends more money for marketing and advertising but customer's loyalty helps to talk about goods and products publicly without any cost. Loyal customers act as a brand ambassador. It is very difficult to satisfy every customer like wrong deliver, not deliver goods in time, and damage products etc. that damage the reputation of business. If there is loyal customer then they will forgive the company when difficulties occur. Customers provide honest and positive feedback to the company so it helps to change negative things.

Loyal customers are very important that help to protect the business in this modern time because there are many businesses, which are providing more facilities and services. So, customer loyalty makes strong business and gives an effort to compete with other business. Loyal customers always show honest and high-quality feedback. Loyal customers always help to improve the business' products and services by giving solicit feedback (Ranabhat, 2018). They always provide the business solicit feedback as well as also help to measure customer experience and satisfaction. If the business wants to launch and test the new products and brands then they can utilize them in 
their loyal customers and can receive their feedback about the products or services (Ranabhat, 2018).

\section{Price of product $(0.106)$ :}

Pricing might not be as glamorous as promotion, but it is the most important decision a marketer can make. Price is important to marketers because it represents marketers' assessment of the value customers see in the product or service and are willing to pay for a product or service.

The other elements of the marketing mix (product, place and promotion) may seem to be more glamorous than price, and thus get more attention, but determining the price of a product or service is actually one of the most important management decisions. While product, place and promotion affect costs, price is the only element that affects revenues, and thus, a business's profits. Price can lead to a firm's survival or demise (Burnett, 2013).

A customer can either be the ultimate user of the finished product or a business that purchases components of the finished product. It is the customer that seeks to satisfy a need or set of needs through the purchase of a particular product or set of products. Consequently, the customer uses several criteria to determine how much they are willing to expend, or the price they are willing to pay, in order to satisfy these needs. Ideally, the customer would like to pay as little as possible.

For the business to increase value, it can either increase the perceived benefits or reduce the perceived costs. Both of these elements should be considered elements of price. In markets with increasing volume and price pressure, the right pricing approach is essential to remain competitive. It brings the company value you deserve for your products and services offered and secures the profits you need to invest in change and growth. Santoso (2002) regards appropriate pricing in line with advertising as a factor contributing to customers' loyalty. If products of a brand have both appropriate price and appropriate quality, then they satisfy the customers and convince them to refer to the same brand in the future. After gaining customers' loyalty, customers will be no longer sensitive to price changes and will rely more on the brand.

\section{Value of corporate brand $(0.087)$ :}

Corporate branding holds an important place in marketing, for both small and large companies. A successful corporate brand is defined by the company's mission, values, and objectives. The purpose of adopting a corporate brand is to have a unique and consistent look and feel across every medium. A basic tenant of marketing is the establishment of a brand identity for products and services. Branding needs are not limited solely to the marketing of products. Corporate branding helps customers relate to a business and identify a wide range of product offers over time. Effective branding minimizes the need for large marketing initiates for every new product as the consumer has a pre-set understanding of the product's quality, reliability and purpose. Establishing a corporate brand requires a commitment to a long-term plan for marketing and product consistency. Focusing on the future, while managing day-to-day operations, helps focus on quality, orient employee energy and drive the company toward a shared vision. The corporate brand influences both the core of the company as much as the customers (Acevedo, 2019).

Corporate branding allows marketing efforts to easily target the most appropriate segments for product offers. The branding distinguishes a company by lifestyle, geography and socioeconomic factors. Branding helps consumers select products appropriate for their needs, desires or wants. The branding also supports the pricing strategy for the target market. For example, a luxury brand presents a refined, high-class image to justify a high price point.

Research and practice have not fully realized the importance of corporate brand images for supporting a firms' product portfolio. In particular, (corporate) marketing managers need to consider the potential value of favorable perceptions of corporate brand innovativeness across products and the moderating role of brand architecture (Brexendorf \& Keller, 2017).

\section{Conclusion}

It may be generally concluded that based on AHP method in determining the reputation criteria effective in administrative furniture industry; quality of product, customer's loyalty, price of product and value of corporate brand gain top have priorities. Having paid attention to these factors and analyzing them in line with realizing them by solutions offered especially training managers skilled in reputation, administrative furniture manufacturers and exporters may gain their standing in the domestic and foreign markets and increase furniture export in addition to that. 
Therefore, presuppositions of the present research are accepted; that is: Quality of product and customer's loyalty are among the most important indicators affecting reputation in the furniture industry.

\section{Appendix A. Supplementary material}

Supplementary data associated with this article can be found, in the online version, at https://doi.org/10.14254/jems.2019.4-2.1

\section{Funding}

The authors received no direct funding for this research.

\section{Citation information}

Azizi, M. (2019). Factors affecting the reputation of administrative furniture. Economics, Management and Sustainability, 4(2), 6-20. doi:10.14254/jems.2019.4-2.1

\section{References}

Acevedo, L. (2019, July 11). The Importance of Corporate Branding. Retrieved from https://smallbusiness.chron.com/ importance- corporate- branding-26160.html

Asgharpoor, M.J. (1999). Multi-criteria decision making. Tehran, Iran: University of Tehran.

Azizi, M. (2005). Decision making for raw material procurement in paper making factory, proceeding of 8th International Symposium of the AHP, University of Hawaii, Honolulu.

Brexendorf, T., \& Keller, K. (2017). Leveraging the corporate brand: The importance of corporate brand innovativeness and brand architecture. European Journal of Marketing, 51(9-10), 1530-1551.

Bunting, M., \& Lipski, R. (2000). Drowned out? Rethinking corporate reputation management for the Internet. Journal of Communication Management, 5(2), 170-178.

Burdurlu, E., \& Ejder, E. (2003). Location choice for furniture industry firms by using Analytic Hierarchy Process (AHP) method. G.U. Journal of Science, 16(2), 369-373.

Burnett, J. $(2013$, July 1). Introduction to Price. Retrieved from https://courses.lumenlearning.com/boundless-marketing/chapter/introduction- to-price

Caruana, A., \& Ewing, M. T. (2010). How corporate reputation, quality, and value influence online Loyalty. Journal of Business Research, 63 (9-10), 1103-1110.

Chinguwa, S., Madanhire, I., \& Musoma, T. (2013). A Decision Framework based on Aggregate Production Planning Strategies in a Multi-Product Factory: A Furniture Industry Case Study. International Journal of Science and Research (IJSR), 2(2), 370-383.

Ghazanfari, A. (2008). Entrepreneurs, Proceedings of Research: Second International Conference on Branding (pp. 35-38). Tehran, Iran.

Haghighi, M., Sefidgaran, B., \& Borhani, B. (1999). Management theory. Tehran, Iran: Naghshemehr.

Inglis, R., Morley, C., \& Sammut, P. (2006). Corporate reputation and organizational performance: an Australian study. Management Auditing Journal, 21(9), 934-947.

Karimi, M. (2011). Comparison of chain store customer loyalty and cultural welfare (Unpublished Master thesis).

Khorshidi, G., \& Kardgar, M. (2009). Identify and rank the most important factors affecting customer loyalty with multi-criteria decision making techniques. Landscape Management Journal 33, 177-191.

Mahdavinia, M. (2002). Management of marketing. Tehran, Iran: Gerayesh.

Memariani, A., \& Azar, A. (1995). AHP: A New Technique for Group Decision Making. Management Science, 28, 22-32.

Memariani, A., Kishore, N., \& Naziri, K. (1992). How to make decision in conflicting environment:Analytical Hierarchy Process. Udyog Pragati, 16, 32-35. 
Ranabhat, D. (2018, March 1). Customer loyalty in business. Retrieved from https://www.theseus.fi/bitstream/handle/10024/.../Ranabhat\%20Durga\%20.pdf?

Renda, A., Pelkmans, J., Schrefler, L., Luchette, G., Simonelli, F., Mustilli, F., Wieczorkiewicz, J., \& Busse, M. (2014, August 1). The EU furniture market situation and a possible furniture products initiative.

Retrieved

from http://publications.europa.eu/resource/cellar/64921615-f0c9-4577-90878f25748ad5d8.0001.01/DOC_1

Saaty, T. (2000). Decision making for leaders. Pittsburg, PA: RWS.

Saaty, T., \& Cho, Y. (2001). The Decision by the US Congress on China's Trade Status: a Multi-criteria analysis. Socio-Economic Planning Sciences, 35, 243- 252.

Santoso, S. (2002). Competitive Analysis in Industry and Marketing Strategy to Face The Competition in Printing Business. Jurnal Ilmiah Kesatuan, 2(2), 9-13.

Tayyar, P. (2012). Supporting national production with the National Quality Standard. National Iranian Magazine. 224, 6-21.

Walsh, G., Dinnie, K., \& Wiedmann, K. (2006). How do corporate reputation and customer satisfaction impact customer defection? Journal of Services Marketing, 20(6), 412-420.

Waters, D. (2011). Quantitative methods for business, Edinburgh, England: Pearson.

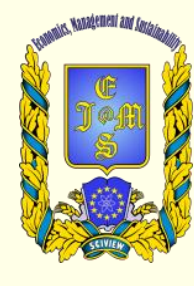

(c) 2016-2019, Economics, Management and Sustainability. All rights reserved. This open access article is distributed under a Creative Commons Attribution (CC-BY) 4.0 license.

You are free to:

Share - copy and redistribute the material in any medium or format Adapt - remix, transform, and build upon the material for any purpose, even commercially.

The licensor cannot revoke these freedoms as long as you follow the license terms.

Under the following terms:

Attribution - You must give appropriate credit, provide a link to the license, and indicate if changes were made.

You may do so in any reasonable manner, but not in any way that suggests the licensor endorses you or your use. No additional restrictions

You may not apply legal terms or technological measures that legally restrict others from doing anything the license permits.

Economics, Management and Sustainability (ISSN: 2520-6303) is published by Scientific Publishing House "CSR",

Poland, EU and Scientific Publishing House "SciView", Poland

Publishing with JEMS ensures:

- Immediate, universal access to your article on publication

- High visibility and discoverability via the JEMS website

- Rapid publication

- Guaranteed legacy preservation of your article

- Discounts and waivers for authors in developing regions

Submit your manuscript to a JEMS at http://jems.sciview.net or submit.jems@sciview.net

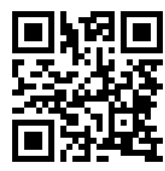

